\title{
Advanced Phase Chronic Myeloid Leukemia Treatment and Transplantation
}

\author{
Zafer GULBAS \\ Anadolu Medical Center Hospital, Bone Marrow Transplantation Center, Kocaeli, TURKEY
}

\begin{abstract}
Imatinib and second generation tyrosine kinase inhibitors has dramatically improved outcomes in patients with chronic myeloid leukemia but allogeneic hematopoietic stem cell transplantation remains an important treatment option in patients who failed imatinib and or second generation second generation tyrosine kinase inhibitors or progressed accelerated and blastic phase. This article provides recommendations regarding the selection of allogeneic hematopoietic stem cell transplantation for patients with chronic myeloid leukemia based on the evaluation of published articles and expert recommendations.
\end{abstract}

Keywords: Chronic myeloid leukemia, Allogeneic hematopoietic stem cell transplantation, Imatinib,

Tyrosine kinase inhibitors

ÖZET

\section{Ileri Faz Kronik Myeloid lösemi tedavisi ve Transplantasyon}

Imatinib ve ikinci jenerasyon tirozin kinaz inhibitörleri; kronik myeloid lösemi hastalarında klinik sonuçları oldukça iyileştirmekle beraber, allojenik hematopoietik kök hücre transplantasyonu; imatinib ve ikinci jenerasyon tirozin kinaz inhibitörleri tedavisine yanıtsız veya akselere ve blastik fazdaki hastalarda önemli bir tedavi seçeneği olarak yerini korumaktadır. Bu makale ilgili literatür ve uzman görüşleri doğrultusunda, kronik myeloid lösemi hastalarında allojenik hematopoietik kök hücre transplantasyonu tedavisi seçimine yönelik önerileri sunmaktadır.

Anahtar Kelimeler: Kronik myeloid lösemi, Allojenik hematopoietik kök hücre transplantasyonu, Imatinib, Tirozin kinaz inhibitörleri 


\section{INTRODUCTION}

While Imatinib (IM) or second generation tyrosine kinase inhibitors (Dasatinib, Nilotinib) supplant the allogeneic hematopoietic stem cell transplantation (allo-SCT) in newly diagnosed chronic myeloid leukemia (CML), some patients are known to be still refractory to imatinib (IM) and tyrosine kinase inhibitors (TKIs).$^{1-3}$ Patients refractory to IM treatment compose $35 \%$ of CML patients and half of these patients are also refractory second generation TKIs. ${ }^{3-6}$ The mortality risk of the allogeneic transplant has decreased continuous-ly during the last 20 years. The reasons for the dramatic improvements include better human leukocyte antigen typing, more careful patient selection and improved supportive care. Reduced leukemia burden by imatinib, nilotinib or dasatinib prior to transplantation may also have contributed to current TRM rates of less than $10 \%$ in CP-CML patients. ${ }^{4,6}$ In this respect, a literature based summary of indication and timing of allogeneic hematopoietic stem cell transplantation in treatment refractory patients is presented in this paper based on the identification of these patients in the first place or with respect to response obtained during the follow up.

\section{Transplant Related Factors}

Certain factors related to allogeneic BMT methodology including donor selection, source of stem cell, preparation regime and measures used to reduce the risk of graft versus host disease influ- ence the success of stem cell transplantation. ${ }^{3,47}$ While bone marrow is recommended source of stem cell for the first chronic phase, use of stem cells obtained from the peripheral circulation is associated with better outcome in advanced phase CML. ${ }^{4,-9}$ Notably, there is an ongoing debate on the inclusion of myeloablative and non-myeloablative preparation regimes. In this regard, decrease in toxicity was reported with patient-dependent dose adjustment of busulfan while preparation regimes were recommended to target the increase of graft versus leukemia effect which has been considered to be more effective in the eradication of the disease compared with high dose chemotherapy. Accordingly, fludarabine containing protocols become the preferred preparation regimes. Additionally, preparation regimes based on $\mathrm{T}$ lymphocyte depletion were documented to be associated with retarded immune recovery and increased risk of infection and relapse. Treatment with imatinib before allogeneic SCT had a positive impact on the probability of survival and second generation tyrosine kinase inhibitors before allogeneic SCT do not adversely affect allogeneic $\mathrm{SCT} ., 4,5,6,9$

\section{Prognostic Scores and Allogeneic Stem Cell Transplantation}

Considering factors related to prognosis; age, spleen size, the ratio of blast in the peripheral blood and thrombocyte count demonstrated by Sokal et al was followed by addition of two other factors as

Table 1. Sokal and Hasfford risk calculation

\begin{tabular}{|llll|}
\hline Study & Calculation & \multicolumn{2}{l|}{ Risk definition by calculation } \\
\hline Sokal et al. & $\begin{array}{l}\text { Exp. } 0.116 \times(\text { age in years }-43.4)+0.0345 \times \\
(\text { spleen }-7.51)+0.188 \times\left[(\text { platelet count }: 700)^{2}\right.\end{array}$ & Low & $<0.8$ \\
& $-0.563]+0.0887 \times($ blas tcells -2.10$)$ & Intermediate & $0.8-1.2$ \\
& & High & $>1.2$ \\
Hasford et al. & 0.666 when age $\geq 50$ years $+(0.042 \times$ spleen $)+$ & Low & $\leq 780$ \\
& 1.0956 when platelet count $>1500 \times 10^{\circ} \mathrm{L}+$ & Intermediate & $781-1480$ \\
& $(0.0584 \times$ blast cells $)+.20399$ when basophils & High & $>1480$ \\
& $>3 \%+(0.0413 \times$ eosinophils $) \times 100$ & & \\
\hline
\end{tabular}


Table 2. Definitions for accelerated and blastic phases

\section{Accelerated phase}

In the peripheral circulation or bone marrow Blast 10-19\%

In the peripheral circulation or bone marrow Blast + promyelocyte $\geq 30 \%$

In the peripheral circulation Basophil $\geq \% 20$

Treatment independent persistent thrombocytopenia $<100 x$ $10^{\circ} / \mathrm{L}$

Persistent thrombocytosis (> $1000 \times 10^{9} / L$ ) uncontrolled by therapy

Persistent increasing spleen size and leukocyte count refractory to treatment

Additional cytogenetic clonal abnormality

\section{Blastic phase}

In the peripheral circulation or bone marrow Blast 20\%

Extramedullary manifestation (chloroma)

Blast cell groups in bone marrow biopsy

Table 3. Transplantation: EBMT risk score calculation

\section{Score}

\section{Donor type}

HLA-matched

0

Other

Phase of the disease

Chronic phase

Accelerated phase

Blastic phase

$$
0
$$

Age

$$
\begin{aligned}
& <20 \text { years } \\
& 20-40 \text { years }
\end{aligned}
$$

$>40$ years

\section{Donor-recipient gender difference}

Female donor, male recipient

Other combination

Time from diagnosis to transplantation
$<12$ months
$>12$ months

0
Table 4. Relation of total EBMT risk score to 5-year survival

\begin{tabular}{|lll|}
\hline Risk factors & TRM (\%) & $\mathbf{5}$ year survival (\%) \\
\hline $0-1$ & 20 & 70 \\
2 & 30 & 60 \\
3 & 50 & 50 \\
4 & 55 & 35 \\
$5-7$ & 70 & 25 \\
\hline
\end{tabular}

Table 5. Criteria for imatinib failure

\section{Imatinib failure}

Progression from chronic phase to accelerated phase during treatment

Loss of hematologic remission

Loss of cytogenetic remission

Evidence of $\geq 0.5 \log (\mathrm{Q}-\mathrm{PCR})$ increase in molecular analysis among patients with complete cytogenetic remission

Detection of mutation in abl kinase domain

Failure to achieve complete hematologic response by $3 \mathrm{rd}$ month

Failure to achieve major cytogenetic response by 12 months

Failure to achieve a complete cytogenetic response by 18 months

basophil and eosinophil counts by Hasford et al. Besides, a scoring system was identified by Gratwohl et al considering age of the patient, type of the donor, phase of the disease, time from the initial diagnosis and gender of the donor in male patients. Indicating better survival following allogeneic SCT in patients with lower scores such as 0.1 , the relation of this scoring system to allogeneic BMT-survival was demonstrated. . $^{1,410,11}$

Detailed information about Sokal and Hasfford risk calculation, accelerated phase and blastic phase definitions ${ }^{11-12}$, transplantation-EMBT risk calculation, imatinib failure, indications for transplanta- 
Table 6. Indications for transplantation in the first chronic, accelerated and blastic phases of the disease

\section{Indications for transplantation}

\section{First chronic phase}

While not recommended without imatinib treatment, excluding patients with T315I mutation, if patient refuses to receive imatinib treatment and prefer transplantation despite explanation of all of the related risks, it can be performed.

Under imatinib treatment: if refractoriness develops, patient is evaluated for second generation TKI treatment as well as allogeneic SCT. Allogeneic SCT is recommended in imatinib refractory patients with mutation and low EBMT score (0-2). According to Hammersmith scoring system, allogeneic SCT is preferred in patients having high sokal risk score, developing neutropenia during imatinib treatment, and more importantly having inadequate cytogenetic response with imatinib besides low EBMT score.

Patients administered with second generation TKI following imatinib treatment or patients with suboptimal response under second generation TKI treatment according to ELN criteria.

\section{Accelerated phase}

Allogeneic SCT is indicated but treatment with high dose imatinib $(600 \mathrm{mg})$ or with second generation TKI in refractory patients to enable hematologic, cytogenetic and molecular remission before the transplantation increases the transplantation success.

\section{Blastic phase}

Allogeneic SCT is indicated following achievement of chronic or accelerated phase of the disease by high dose imatinib (600 mg), second generation TKI or combination chemotherapy.

Table 7. Indications for tyrosine kinase inhibitor treatment following allogeneic stem cell transplantation, age criteria for transplantation and timing of donor search

\section{Indications for tyrosine kinase inhibitor treatment following transplantation}

It is recommended as a prophylactic treatment in patients with allogeneic stem cell transplantation due to positive ALL and blastic phase CML.

Patients with cytogenetic and molecular relapse following transplantation

\section{Age criteria for transplantation}

Related or unrelated myeloablative allogeneic SCT: up to 55 years of age

Related and Unrelated nonmyeloablative allogeneic SCT: up to 65 years of age

\section{Timing of donor search}

Patients refractory to imatinib treatment

Patients in the accelerated or blastic phase of the disease

Patients less than 20 years old

Patients with high risk and clonal chromosome abnormalities

Patients with suboptimal response to second generation TKls and EBMT score 0-2 
tion in the first chronic, accelerated phase and blastic phases of the disease, indications for the treatment with tyrosine kinase inhibitors after allogeneic stem cell transplantation, age criteria for transplantation and timing of donor search are summarized in Tables 1-7.

\section{The Value of Post Transplant Use of TKI}

It is recommended as a prophylactic treatment in patients with allogeneic stem cell transplantation due to positive ALL and blastic phase CML or patients with cytogenetic and molecular relapse following transplantation. Articles related the use of imatinib and second-generation TKIs in the postSCT setting are limited. The incidence of GVHD in patients treated with Imatinib and second-generation TKIs post transplant is not yet known. Imatinib and second-generation TKIs during the post-SCT can cause pancytopenia, QTC prolongation, cardiotoxicity, liver dysfunction, fluid retention and nausea but the drugs is generally well tolerated. It is also unclear whether post-SCT Imatinib and second-generation TKIs alone is sufficient to induce durable remissions. Between Imatinib and secondgeneration TKIs, Dasatinib crosses the blood-brain barrier and has a role in the treatment of extramedullary relapse. Imatinib and second-generation TKIs do not eradicate the leukemic stem cell and donor lymphocyte infusions can be given for this purpose. More studies are warranted to identify the best time post-SCT to initiate therapy with TKIs, long-term side effects, treatment duration. ${ }^{6,7,13}$

\section{CONCLUSION}

Early identification of poor risk CML patients for allo-SCT is important. Evaluating the hematologic, molecular and cytogenetic response to Imatinib and second generation tyrosine kinase inhibitors and prognostic factors are useful for deciding allogeneic BMT in patients with CML.

\section{REFERENCES}

1. Milojkovic D, Nicholson E, Apperley JF, et al. Early prediction of success or failure of treatment with secondgeneration tyrosine kinase inhibitors in patients with chronic myeloid leukemia. Haematologica 95: 224231, 2010.

2. Gratwohl A, Brand R, Apperley J, et al. Allogeneic hematopoietic stem cell transplantation for chronic myeloid leukemia in Europe 2006: transplant activity, long-term data and current results. An analysis by the Chronic Leukemia Working Party of the European Group for Blood and Marrow Transplantation (EBMT). Haematologica 91: 513-521, 2006.

3. Radich JP. Allogeneic transplant for chronic myeloid leukemia in 2010. Therapeutic Advances in Hematology 1: 5-13, 2010.

4. O'Brien S, Berman E, Moore JO, NCCN Task Force Report: Tyrosine Kinase Inhibitor Therapy Selection in the Management of Patients With Chronic Myelogenous Leukemia. JNCCN 9 [Suppl 2]: S1-S25, 2011.

5. Pavlu J, Kew A, Taylor-Roberts B, et al. Optimizing patient selection for myeloablative allogeneic hematopoietic celltransplantation in chronic myeloid leukemia in chronic phase Blood. 2010; 115: 40184020, 2010.

6. Pavlu J, Szydlo RM, Goldman JM, Apperley JF. Three decades of transplantation for chronic myeloid leukemia: what have we learnt? Blood 117: 755-763, 2010.

7. Baccarani M, Castagnetti F, Gugliotta G et al . Response definitions and European Leukemianet Management recommendations Best Practice \& Research Clinical Haematology 22: 331-341, 2009.

8. Oyekunle A, Klyuchnikov E, Ocheni S, et al. Challenges for Allogeneic Hematopoietic Stem Cell Transplantation in Chronic Myeloid Leukemia in the Era of Tyrosine Kinase Inhibitors. Acta Haematol 126: 30-39, 2011.

9. Baccarani M, Cortes J, Pane F, et al. Chronic myeloid leukemia: an update of concepts and management recommendations of European LeukemiaNet. J Clin Oncol 27: 6041-6051, 2009.

10. Gratwohl A, Hermans J, Goldman JM, et al. Risk assessment for patients with chronic myeloid leukaemia before allogeneic blood or marrow transplantation. Chronic Leukemia Working Party of the European Group for Blood and Marrow Transplantation. Lancet 352: 1087-1092, 1998. 
11. Passweg JR, Walker I, Sobocinski KA, et al. Validation and extension of the EBMT Risk Score for patients with chronic myeloid leukaemia (CML) receiving allogeneic haematopoietic stem cell transplants. $\mathrm{Br} J$ Haematol 125: 613-620, 2004.

12. Vardiman JW, Melo JV, Baccarani M, et al. Chronic myelogenous leukaemia, BCR/ABL1 positive. In Swerdlow SH, Campo E, Harris NL, et al. eds. WHO Classification of Tumours of Hematopoietic and Lymphoid Tissues. Lyon, France, IARC Press, 2008: 3237.

13. Venepalli N, Rezvani K, Mielke S, Savani BN. Role of allo-SCT for CML in 2010. Bone Marrow Transplant 45: 1579-1586, 2010.

\section{Correspondence}

Dr. Zafer GÜLBAŞ

Özel Anadolu Sağlık Merkezi Hastanesi

41400 Gebze, Kocaeli / TURKEY

Tel: (+90.262) 6785573

Fax: (+90.262) 6540055

e-mail: zgulbas@superonline.com 